\title{
One Health operational framework for action for the Eastern Mediterranean Region, focusing on zoonotic diseases
}

\author{
Heba Mahrous, ${ }^{1}$ Nesre Redi, ${ }^{1}$ Tran Minh Nhu Nguyen, ${ }^{2}$ Salah Al Awaidy, ${ }^{3}$ Ehsan Mostafavi, ${ }^{4}$ Dalia Samhouri ${ }^{1}$
}

${ }^{1}$ World Health Organization Regional Office for the Eastern Mediterranean, Cairo, Egypt (Correspondence: H. Mahrous: hmahrous@who.int; hebarisha@gmail.com). ${ }^{2}$ World Health Organization Country Office for India, Delhi, India. ${ }^{3}$ Ministry of Health, Muscat, Oman. ${ }^{4}$ Research Centre for Emerging and Re-emerging Infectious Diseases, Pasteur Institute of Iran, Tehran, Islamic Republic of Iran.

\begin{abstract}
Human health is intrinsically linked to the health of animals and to the environment, and efforts by just one sector alone cannot prevent or adequately address the complex problems at the human-animal-environment interface. Countries of the World Health Organization Eastern Mediterranean Region, as any other region, face the threat of emerging and remerging zoonoses. However, the challenges in this Region are high given the lack of resources, poor health systems, and political factors. Hence, adopting the One Health approach becomes urgent to assist those countries. Subsequently, based on analysis of One Health capacities in the Region and in close consultation with representatives and subject matter experts from countries in the Region, a framework for action towards effectively implementing the One Health approach was developed. The framework capitalizes on current opportunities in the region and provide countries with a list of practical key activities towards optimal use of their resources and strengthening their capabilities to tackle concurrent and future health challenges at the interface. Strong governance structures and building on existing mechanisms are crucial for achieving effective disease surveillance and response. Additionally, using intersectoral approaches for risk assessment and risk mitigation for health issues at the human-animal-environment interface can improve efficiency and result in more successful outcomes.

Keywords: One Health, human-animal interface, framework for action, zoonoses, Eastern Mediterranean Region

Citation: Mahrous H; Redi N; Nguyen N; Al Awaidi S; Mostafavi E, Samhouri D. One Health operational framework for action for the Eastern Mediterranean Region, focusing on zoonotic diseases. East Mediterr Health J. 2020;26(6):720-725. https://doi.org/10.26719/emhj.20.017

Received: 27/06/19; accepted: 26/11/19

Copyright (C) World Health Organization (WHO) 2020. Open Access. Some rights reserved. This work is available under the CC BY-NC-SA 3.o IGO license (https://creativecommons.org/licenses/by-nc-sa/3.o/igo)
\end{abstract}

\section{Introduction}

Emerging and endemic zoonotic diseases pose a threat to animal and human health and to global health security (1). It is estimated that zoonoses are responsible for 2.5 billion cases of human illness and 2.7 million deaths worldwide each year (2). The global economic burden due to zoonotic diseases is tremendous. According to the World Bank estimate, the economic losses from 6 major outbreaks of fatal zoonoses [Nipah virus (Malaysia), West Nile fever (United States of America; USA), severe acute respiratory syndrome (Asia, Canada and others), highly pathogenic avian influenza (Asia and Europe), bovine spongiform encephalitis (USA and United Kingdom of Great Britain and Northern Ireland), Rift Valley fever (United Republic of Tanzania, Kenya, and Somalia) between 1997 and 2009 amounted to at least US\$80 billion (3). The recent Ebola virus epidemic in West Africa is a stark reminder of the role animal reservoirs play in public health and reinforces the urgent need for a global One Health approach, as efforts by one sector alone cannot prevent or adequately address these complex problems at the human-animal-environment interface (2).

The One Health approach, according to the Tripartite Zoonoses Guide, means that all relevant sectors and disciplines across the human-animal-environment interface are involved in addressing health in a coordinated way that is more effective, efficient or sustainable than might be achieved if not all relevant sectors were engaged (4). This coordination/collaboration is required to detect, assess and respond to both high-impact zoonotic disease events and endemic zoonoses caused by infectious organisms that know no boundaries, and whose impact on individuals and communities goes beyond the direct health outcomes to affect economies and societies as a whole (5). Over the years, the scope of One Health has extended to include food security, food safety, antimicrobial resistance and strengthening health systems (6-8).

The lack of surveillance data on emerging zoonoses in many developing countries, the fact that surveillance is mostly event based, and incomplete inventory of pathogens that exists in mammalian and other reservoirs have led to underestimation of their burden on humans, livestock and wildlife, and have limited the possibility of their control (9).

The World Health Organization (WHO) Eastern Mediterranean Region suffers from acute and chronic problems such as economic restrictions, conflict, civil war, social unrest, political instability, human migration and transboundary animal movement, which have had implications for emergence, control and management of zoonotic diseases such as avian influenza, brucellosis, rabies, Crimean-Congo haemorrhagic fever, Middle Eastern respiratory syndrome and transboundary animal 
diseases (10-13). Furthermore, lack of reliable data at national/regional levels due to absence of continuous systematic surveillance of zoonotic diseases, as well as lack of or weak intersectoral collaborations, policies, strategies and programmes, coupled with insufficient trainings for professionals in crucial technical areas have contributed to failure of control and management activities (14-16).

The purpose of this paper is to provide a brief explanation of the One Health operational framework, including its establishment, main components, road map activities, and key recommendations on how it could be implemented and adapted to each country's context. Furthermore, we identify systems, mechanisms and practices to address and respond better to, endemic, emerging and re-emerging zoonotic diseases in a multisectoral manner.

\section{Methodology}

The One Health operational framework is built upon the findings of the International Health Regulation's Joint External Evaluation (IHR-JEE) reports, National Action Plan for Health Security (NAPHS) and the IHRPVS National Bridging Workshops (NBW). The JEE, NAPHS and NBW were conducted in 18, 12 and 3 countries, respectively, out of the 22 countries of the WHO Eastern Mediterranean Region. The performance of regional countries in zoonoses and other One Health-related technical areas were evaluated, gaps identified, and priority actions to address these gaps recommended (17-19). For instance, a skilled sufficient workforce in the animal health sector is not always available in most of the evaluated countries. This has an adverse effect on detection and response activities, and consequently, on the spread of diseases. There is a persistent need for dedicating new staff and providing them with professional in-service training to create a culture of learning and constructive attitudes, and to build their potential to deal with any challenges at the human-animal-environment interface.

In view of the differences between the countries evaluated in terms of One Health operational capacity, high-priority activities based on gaps identified in the JEE reports, NAPHs and NBWs are proposed in this framework. Furthermore, an expert consultation meeting on One-Health Framework for Action was organized in December 2018 in Amman, Jordan. This included participation from representatives of the Ministries of Health and Ministries of Agriculture of 7 regional countries, WHO Regional Office for the Eastern Mediterranean, Food and Agriculture Organization of the United Nations (FAO), World Organisation for Animal Health (OIE), national agencies, and academic and other partner institutions. Recommendations and inputs from the consultation meeting were incorporated into the document. In general, the framework basically capitalizes on current opportunities and gives direction for strategic investment in preparedness, detection and response to zoonotic diseases across relevant sectors at all levels.

\section{Framework components and roadmap activities}

In most evaluated countries there are capacities on the ground that pave the way and create an enabling environment for enhancing implementation of the One Health approach at the human-animal-environment interface. National committees for zoonoses, food safety and a joint response to zoonotic disease outbreaks are some examples of such capacities. However, there is still a lack of clear terms of reference for the assigned staff; sound coordination mechanisms; effective and timely information sharing among key stakeholders; and a real-time surveillance system for zoonotic diseases. These needs are addressed under this framework through several proposed priority activities grouped into 7 components that are essential for successful implementation of the One Health approach. These components include governance and management; networks and partnerships; One Health workforce development; surveillance preparedness and response; communication and advocacy; applied research; and monitoring and evaluation. They provide a systematic technical basis for countries in the development and implementation of the One Health approach for mitigating health issues of national concern.

WHO Member States are at different stages of implementing the One Health approach. Some countries already have a One Health committee or hub to undertake the responsibility of implementation but need guidance on how this forum can be optimally functional. Other countries still lag behind and do not have clear ideas on how they can start towards having a robust One Health implementation on the ground. Therefore, there is flexibility in activity planning and target setting to meet national requirements. This framework includes a list of roadmap activities under each of the 7 components (Appendix 1). However, countries are encouraged to modify and adapt it in accordance with their needs to develop realistic, achievable and effective plans.

\section{The way forward}

The expert meeting in Amman discussed how to roll out the One Health framework for implementation in the WHO Eastern Mediterranean Region. Despite previous and current international, regional and national efforts to implement a One Health approach, challenges are still holding back progress, such as: the need to work across many different disciplines; administrative barriers; lack of trained and skilled personnel, timely provision of resources, and accredited diagnostic laboratories; understanding the structure and management of existing systems; development of adequate science-based risk-mitigation strategies; lack of agreement on leadership issues; and task distribution among partners $(2,20)$. Accordingly, the framework components have been tailored carefully to assist countries to overcome such challenges. For countries where there are no plans addressing One Health activities, country representatives agreed that there is a need to develop a national operational plan based on this framework 
in close consultation with national stakeholders and using available One Health bodies/initiatives. Then, it has to be advocated and endorsed by ministries of health, ministries of agriculture (veterinary authorities) and other relevant ministries/sectors to support implementation of identified multisectoral activities. For countries that have plans in place, they can use this framework to enhance their existing operational plans with key activities, such as risk assessment, prioritization of zoonotic diseases, preparedness and response activities, assessment of existing capacities, identifying research priorities, and coordination with partners. Participants in the expert meeting acknowledged the added value of the framework as a guiding document for applying the One Health approach in a systematic way, and as a justification for contacting senior officials/ ministers to allocate resources for activities. FAO and OIE requested the framework to be shared with their regional offices so that they can disseminate it to countries through their channels.

The Region is committed to continue providing technical support for regional countries to set up a multisectoral collaboration and coordination mechanism among their professionals in the human health, animal health and environmental sectors, and help countries to develop national plans in order to meet their obligations under the International Health Regulations (2005). Moreover, the Region will organize and facilitate technical expert meetings among countries to share lessons learned, and to facilitate sharing of inter-regional experience.

\section{Acknowledgements}

The World Health Emergencies Programme in the WHO Eastern Mediterranean Region gratefully acknowledges Member States representatives, international organizations (FAO and OIE), partners and subject matter experts for their extensive input to enhance the One Health Operational Framework, and in particular, during the expert consultation workshop organized in Amman/Jordan, December 2018.

Funding: None

Competing Interests: None declared

\section{Cadre d'action opérationnel « Une seule santé » pour la Région de la Méditerranée orientale, accent mis sur les zoonoses}

\section{Résumé}

La santé humaine est intrinsèquement liée à la santé des animaux et à l'environnement, et les efforts d'un seul secteur ne peuvent prévenir ou résoudre de manière adéquate les problèmes complexes à l'interface homme-animal-environnement. Les pays de la Région OMS de la Méditerranée orientale, comme toute autre région, sont confrontés à la menace des zoonoses émergentes et réémergentes. Toutefois, les défis dans cette Région sont importants étant donné la pénurie de ressources, la faiblesse des systèmes de santé et les facteurs politiques. Il devient donc urgent d'adopter l'approche «Une seule santé » pour aider ces pays. Par la suite, sur la base de l'analyse des capacités de l'approche « Une seule santé » dans la Région et en étroite consultation avec les représentants et les experts en la matière des pays, un cadre d'action pour la mise en œuvre efficace de cette approche a été élaboré. Le cadre capitalise sur les opportunités actuelles dans la Région et fournit aux pays une liste d'activités clés pratiques en vue d'une utilisation optimale de leurs ressources et du renforcement de leurs capacités pour relever les défis sanitaires existants et futurs à l'interface. Des structures de gouvernance solides et le renforcement des mécanismes existants sont essentiels pour assurer une surveillance et une riposte efficaces face aux maladies. En outre, l'utilisation d'approches intersectorielles pour l'évaluation et l'atténuation des risques pour les questions liées à santé à l'interface homme-animal-environnement permet d'améliorer l'efficacité et de mener à des résultats plus probants.

$$
\begin{aligned}
& \text { الإطار التشغيلي للصحة الواحدة في إقليم شرق المتوسط، والتركيز على الأمر اض الحيوانية المنشأ } \\
& \text { هبة محروس، نسري ريدي، نهو نجوين، صلاح العويدي، إحسان مصطفاوي، داليا سمهوري }
\end{aligned}
$$

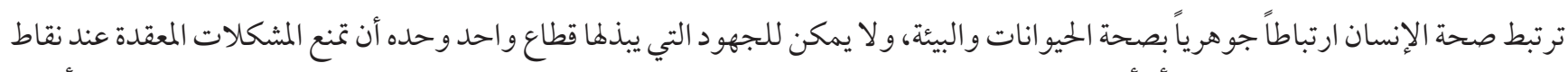

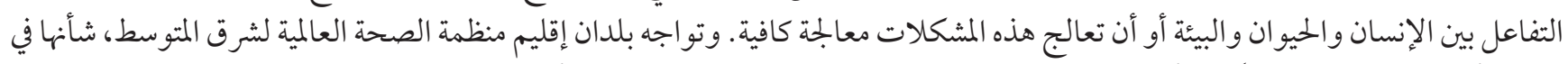

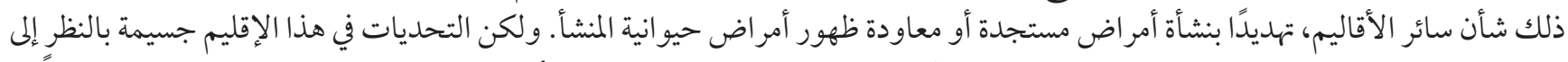

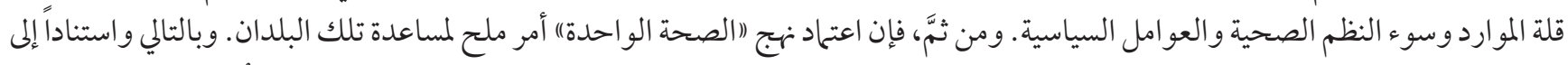
تحليل القدر ات في جال (الصحة الو احدة) في الإقليم وبالتشاور الوثيق مع مثثلي البلدان والخبراء المتخصصين في هذا المجال، وُضع إطار عمل لتنفيذ 


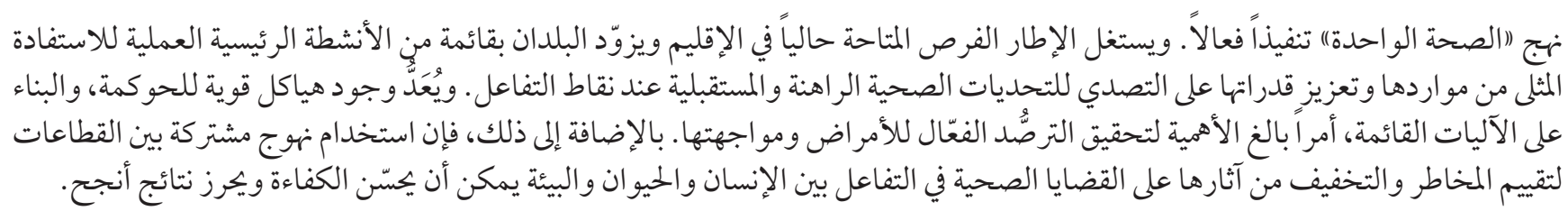

\section{References}

1. Salyer SJ, Silver R, Simone K, Behravesh CB. Prioritizing zoonoses for global health capacity building - themes from one health zoonotic disease workshops in 7 countries, 2014-2016. Emerg Infect Dis. 2017;23(Suppl). https://wwwnc.cdc.gov/eid/article/23/13/17-0418_article

2. Gebreyes WA, Dupouy-Camet J, Newport MJ, Oliveira CJ, Schlesinger LS, Saif YM, et al. The global One Health paradigm: challenges and opportunities for tackling infectious diseases at the human, animal, and environment interface in low-resource settings. PLoS Negl Trop Dis. 2014 Nov 13;8(11):e3257. http://dx.doi.org/10.1371/journal.pntd.0003257 PMID:25393303

3. People, pathogens and our planet : the economics of one health. Washington, DC: World Bank; 2012 (http://documents.worldbank. org/curated/en/612341468147856529/People-pathogens-and-our-planet-the-economics-of-one-health, accessed 4 April 2020).

4. Taking a multisectoral, One Health approach: a tripartite guide to addressing zoonotic diseases in countries. Food and Agriculture Organization of the United Nations; World Organisation for Animal Health; World Health Organization; 2018 (http:// www.sacids.org/wp-content/uploads/2019/03/A-Tripartite-Guide-to-Addressing-Zoonotic-Diseases-in-Countries.pdf, accessed 4 April 2020).

5. Detels R, Gulliford M, Karim QA, Tan CC. Oxford textbook of global public health, 6th edition. Oxford University Press; 2015.

6. J. Zinsstag ES, K. Wyss, M.B. Mahamat. Potential of cooperation between human and animal health to strengthen health systems. Lancet. 2005 Dec 17;366(9503):2142-5. PMID:16360795

7. One Health: Food and Agriculture of the United Nations Strategic Action Plan. FAO; 2011 (http://www.fao.org/3/al868e/al868eoo. pdf, accessed 4 April 2020).

8. Schelling E, Wyss K, Bechir M, Moto DD, Zinsstag J. Synergy between public health and veterinary services to deliver human and animal health interventions in rural low income settings. BMJ. 2005 Nov 26;331(7527):1264-7. http://dx.doi.org/10.1136/ bmj.331.7527.1264 PMID:16308393

9. Merianos A. Surveillance and response to disease emergence. Curr Top Microbiol Immunol. 2007;315:477-509. http://dx.doi. org/10.1007/978-3-540-70962-6_19 PMID:17848076

10. Di Nardo A, Knowles NJ, Paton DJ. Combining livestock trade patterns with phylogenetics to help understand the spread of foot and mouth disease in sub-Saharan Africa, the Middle East and Southeast Asia. Rev Sci Tech. 2011 Apr;30(1):63-85. http://dx.doi. org/10.20506/rst.30.1.2022 PMID:21809754

11. Gwida M, Neubauer H, Ilhan Z, Schmoock G, Melzer F, Nockler K, et al. Cross-border molecular tracing of brucellosis in Europe. Comp Immunol Microbiol Infect Dis. 2012 Mar;35(2):181-5. http://dx.doi.org/10.1016/j.cimid.2011.12.012 PMID:22277829

12. Memish ZA, Al-Rabeeah AA. Public health management of mass gatherings: the Saudi Arabian experience with MERS-CoV. Bull World Health Organ. 2013 Dec 1;91(12):899-899A. http://dx.doi.org/10.2471/BLT.13.132266 PMID:24347725

13. Nowotny N, Kolodziejek J. Middle East respiratory syndrome coronavirus (MERS-CoV) in dromedary camels, Oman, 2013. Euro Surveill. 2014 Apr 24;19(16):20781. http://dx.doi.org/10.2807/1560-7917.es2014.19.16.20781 PMID:24786259

14. Dyer O. Infectious diseases increase in Iraq as public health service deteriorates. BMJ. 2004 Oct 23;329(7472):940. http://dx.doi. org/10.1136/bmj.329.7472.940-a PMID:15499110

15. Horton DL, Ismail MZ, Siryan ES, Wali AR, Ab-dulla HE, Wise E, et al. Rabies in Iraq: trends in human cases 2001-2010 and characterisation of animal rabies strains from Baghdad. PLoS Negl Trop Dis. 2013;7(2):e2075. http://dx.doi.org/10.1371/journal.pntd.ooo2075 PMID:23469303

16. Seimenis A. Capacity building for zoonotic and foodborne diseases in the Mediterranean and Middle East regions (an intersectoral WHO/MZCP proposed strategy). Int J Antimicrob Agents. 2010 Nov;36 Suppl 1:S75-9. http://dx.doi.org/10.1016/j.ijantimicag.2010.06.027 PMID:20708385

17. Strengthening health security by implementing the International Health Regulations (2005). WHO Eastern Mediterranean Region: JEE mission reports (https://www.who.int/ihr/procedures/mission-reports-eastern-mediterranean/en/, accessed 4 April 2020).

18. NAPHS for all a 3 step Strategic Framework for National Action Plan for Health Security. Geneva: World Health Organization; 2018 (https://apps.who.int/iris/bitstream/handle/10665/278961/WHO-WHE-CPI-2018.52-eng.pdf?sequence=1, accessed 4 April 2020).

19. Strategic Partnership for International Health Regulations (2005). IHR-PVS National Bridging Workshop [website] (https://extranet.who.int/sph/ihr-pvs-bridging-workshop, accessed 4 April 2020).

20. Rushton J, Häsler B, De Haan N, Rushton R. Economic benefits or drivers of a 'One Health' approach: why should anyone invest? Onderstepoort J Vet Res. 2012 Jun 20;79(2):461. http://dx.doi.org/10.4102/ojvr.v79i2.461 PMID:23327381 


\section{Appendix 1. Roadmap activities}

\section{Components of the framework}

\section{Governance \\ \& Management}

\section{Objective:}

To ensure that a system is in place to govern, manage, coordinate and oversee all One Health activities.

\section{Activities:}

- Identify a national multisectoral One Health committee from the governmental authorities with clear terms of references

- Develop policies, strategies, operational plans, SOPs necessary for implementing One Health activities.

- Identify/establish a coordination mechanism to maintain ongoing dialogue with stakeholders.

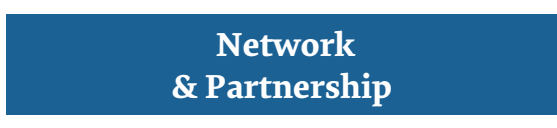

\section{Objective:}

To foster collaboration and partnerships.

\section{Activities:}

- Identify key stakeholders and collaborators, indicate their likely contributions to implementation of One Health activities.

- Develop new/adjust existing mechanisms to regulate and facilitate collaboration and coordination between relevant sectors.

- Establish a unified electronic system to facilitate networking and partnership across sectors.

- Hold regular meeting to ensure smooth implementation of planned activities. 


\section{Appendix 1. Roadmap activities}

Components of the framework

\section{Surveillance, \\ Preparedness \& Response}

\section{Objective:}

To enhance national coordinated surveillance, preparedness and response for prevention, detection and control of zoonotic diseases.

\section{Activities:}

- Draw up a list of priority zoonotic diseases.

- Develop or update and ratify a zoonotic disease strategy.

- Assess/evaluate existing zoonotic disease surveillance systems.

- Establish a joint integrated disease surveillance system with operational plans, guidelines, SOPs and needed facilities.

- Train staff on the integrated disease surveillance system.

- Develop a database/platform and data collection forms to compile and enter surveillance data.

- Conduct joint risk assessment at the humananimal-environment interface for emerging zoonotic diseases.

- Develop a national multisectoral integrated emergency preparedness and response plan for zoonotic events with SOPs.

- Establish multidisciplinary rapid response teams at different administrative levels.

- Train joint rapid response teams from animal and human health sectors.

- Conduct simulation exercises and after action reviews on coordinated response to zoonotic diseases

\section{Communication \&} Advocacy

\section{Objective:}

- To develop multilevel, multisectorial capacity for communication and advocacy, and to gain commitment and support from all sectors

\section{Activities:}

- Identify target audience, responsible sectors (messengers) and communication channels.

- Develop an action plan for risk communication including SOPs.

- Develop functional communication and coordination mechanisms among stakeholders.

- Raise public awareness to encourage disease notification, prevention and containment.

- Provide risk communication training for relevant staff and community members.

- Identify relevant national and international partners, actors and key players according to threats identified and their likely contribution.

- Organize meetings with identified key players to gain their commitment and ensure their effective engagement

\section{Applied research}

\section{Objective:}

To strengthen knowledge about zoonotic pathogens and their mechanism of sustenance and transmission through joint research.

\section{Activities:}

- Identify priority research areas at the human-animal interface.

- Promote applied research collaboration.

- Assess national capacity to conduct the necessary research.

- Prepare joint research proposals on zoonotic pathogens.

- Prepare agreements with national and international partners for collaboration on main research questions.

- Publish or report findings of research activities zoonoses. 